\title{
Comparison of semi-continuous and interrupted suture technique for aortic valve replacement
}

\author{
Q Chen ${ }^{*}$, C Di-Salvo, N Roberts, J Yap \\ From 23rd World Congress of the World Society of Cardio-Thoracic Surgeons \\ Split, Croatia. 12-15 September 2013
}

\section{Background}

Previous study suggested semi continuous technique increases the risk of re-operation for paraprosthetic leak AVR compared with interrupted suture technique. We aim to evaluate our experience in these two techniques performed in our institution.

\section{Methods}

Retrospective review of patients who underwent aortic valve replacement (AVR) with or without combined cardiac procedures from April 2002 to September 2012. The data was collected from hospital electronic data base and medical notes.

\section{Results}

The number of patients underwent AVR including combined cardiac procedures was 1005 with semi continuous technique (group 1) and 1110 with interrupted technique (group 2). The hospital mortality was $4.68 \%$ in group 1 and $3.96 \%$ in group 2. Cardiopulmonary bypass (CPB) time and aortic cross clamp (XC) time for isolated AVR was $89 \pm 42(41-379)$ and $63 \pm 31(29-258)$ in group 1 , $98 \pm 34(44-377)$ and $72 \pm 26(30-236)$ in group 2 , $\mathrm{p}=0.0002, \mathrm{p}<0.0001$, respectively. Late cardiac reoperation was performed in 23 patients (2.3\%) in group 1 and in 24 patients $(2.2 \%)$ in group 2. Late repeat operation for AVR was performed in 5 patients $(0.5 \%)$ in group 1 , and in 5 patients $(0.45 \%)$ in group 2 . There were 51 late deaths (10.9\%) group 1 and 48 late deaths (9.2\%) in group 2.

\section{Conclusions}

The incidence for repeat operation for AVR following primary AVR was low. There was no significant difference in terms of hospital mortality, repeat operation for AVR, and late survival between groups of patients with

\footnotetext{
* Correspondence: qiangchen79@hotmail.com
}

Cardiac Surgery, The Heart Hospital, London, UK semi continuous and interrupted suture techniques. Semi continuous suture technique, however, reduces the $\mathrm{CPB}$ and aortic $\mathrm{XC}$ time compared with interrupted suture technique.

Published: 23 October 2013

doi:10.1186/1749-8090-8-S2-O1

Cite this article as: Chen et al:: Comparison of semi-continuous and interrupted suture technique for aortic valve replacement. Journal of Cardiothoracic Surgery 2013 8(Suppl 2):01.
Submit your next manuscript to BioMed Central and take full advantage of:

- Convenient online submission

- Thorough peer review

- No space constraints or color figure charges

- Immediate publication on acceptance

- Inclusion in PubMed, CAS, Scopus and Google Scholar

- Research which is freely available for redistribution
C Biomed Central (c) 2013 Chen et al; licensee BioMed Central Ltd. This is an Open Access article distributed under the terms of the Creative Commons Attribution License (http://creativecommons.org/licenses/by/2.0), which permits unrestricted use, distribution, and reproduction in any medium, provided the original work is properly cited. 